\title{
Sensation seeking tendency and the preference of experiential learning
}

\author{
Dita Culková, Jan Suk
}

\begin{abstract}
The present descriptive study is based on mixed pre-structured research fundamental strategy of which is a non-intervention questionnaire and more in depth semi-structured interviews. A statistically significant correlation between the degree of tendency to seek sensation and preferences of so-called experiential learning is examined via Pearson's correlation coefficient. The qualitative part of the research verifies whether monitored students with a high tendency to seek extraordinary experiences intuitively and deliberately need experiential learning, while two out of three students with low tendencies to seek extraordinary sensations do not have a deep inner need for experiential learning; however, they welcome the offer of experiential pedagogy when available.
\end{abstract}

Key words: learning, learning style, experiential learning, sensation, sensation seeking tendency, experiencing learning process, grammar school students. 


\title{
Tendence hledání prožitku a preference zkušenostního učení
}

\begin{abstract}
Abstrakt
Tato popisná studie je založena na smíšené základní strukturované výzkumné strategii, jejímž základem je neintervenční dotazník a podrobnější polo-strukturované rozhovory. Statisticky významná korelace mezi stupněm tendence hledat prožitek a preferencemi tzv. zážitkového učení je zkoumána pomocí Pearsonova korelačního koeficientu. Kvalitativní část výzkumu ověřuje, zda sledovaní studenti s vysokou tendencí intuitivně a záměrně hledají zážitkové učení, zatímco dva ze tří studentů s nízkou tendencí hledat mimořádné prožitky nemají hlubokou vnitřní potřebu zkušenostního učení; v prípadě, že je k dispozici, však vítají nabídku zážitkové pedagogiky.
\end{abstract}

Klíčová slova: učení, styl učení, zkušenostní učení, prožitek, tendence hledání prožitku, prožívání procesu učení, studenti gymnázií.

DOI: $10.5507 /$ epd.2019.016

\section{Introduction}

The aim of the present study is to contribute to the discourse concerning improvements in the educational process. In particular, the paper addresses the issue of experience in connection with sensation seeking tendencies.

\section{Research Methodology}

The examined issue is specified by two research questions and one alternative hypothesis:

\subsection{Research questions and hypothesis}

1. Is it possible to locate a statistically significant correlation between the degree of tendency to seek sensations and preference for experiential learning of the monitored group?

2. How do students with high and low sensation seeking tendencies consider their need to experience the learning process? 
Hypothesis

$\mathrm{H}_{1}$ : There is a statistically significant correlation between the tendency to seek sensations and the preference of experiential learning among students.

\subsection{Research Focus}

The basic concepts in this study are the learning style defined by Rita Dunn (Dunn, 2000), her Learning style inventory with a variable called experiential learning, and the sensation seeking tendency in the concept of Marvin Zuckerman (Zuckerman, 1978). Sensation is understood as a new, strong and exceptional experience, and it is used in the context of the sensation seeking tendency (SST). This tendency is determined by both the genetic and environmental factors (Zuckerman, 1994). It is related to risk-taking and boredom (Zuckerman, 2001) and is an essential part of a pupil's personality. Expressions ensuring sufficient saturation of extraordinary experience, the amount of which is individual, can have both a positive and negative character. The studies explicitly related to the SST and to education (Farley, 1981; Wentzel, 1993; Stewin \& Carter, 1999; Blum, Beuhring \& Rinehart, 2000; Ang \& Woo, 2003) demonstrate that students with a high SST have a negative approach to school attendance and are more inclined to hyperactivity and crime than students with a low SST. It indicates a link between the sensation seeking tendency, poor study skills and general dissatisfaction with teachers, the school and the learning process. A preference for experiential learning may correlate with the amount of tendency to seek extraordinary experiences, and often correlates with the issue of boredom. The need to experience is examined in questionnaire form by Rita Dunn (Dunn, 2000) with the reliable called experiential or kinaesthetic learning respectively. The authors Pettigrew and Zakrajsek (1984), Johnston and Bower (1997), D. Peters, Jones and J. Peters (2008) claim that students preferring the so-called "hands on" experience and active experiments are Physical Education students. Similarly, Rybenský (2008), Krásová and Rost (2008) and Kuban (2001) demonstrate that followers of a specific lifestyle, particularly young people engaged in various sports, show higher (above average) sensation seeking tendency. Also, for this reason, this study was carried out among students of secondary schools (more particularly secondary grammar schools, known also as gymnasia) with extended physical education and sports training.

\subsection{General Research Background}

The general approach of the present descriptive study is mixed research by quantitative data processing which is complemented by qualitative methods. The research itself is pre-structured and its fundamental strategy is non-intervention questionnaire research combined with in-depth semi-structural qualitative interviews. 


\subsection{Research Sample}

\section{Quantitative section}

The research group was selected by random stratified selection of Czech grammar schools (gymnasia) which offer study programmes with extended physical education and sports training. The basic set of schools was taken from the Institute for Information on Education and it consisted of 16 institutions. Using random selection ten schools were selected and seven of them became involved in this study while three schools refused to participate. Of these seven schools, third grade students (in four-year programmes), and seventh grade students (eight-year programmes) were questioned. The final number of completed questionnaires was 300 .

\section{Qualitative section}

The research file consisted of six purposefully selected students from the third grade of the four-year programme and seventh grade from the eight-year programme at a secondary grammar school in Liberec. Based on their data value input concerning the degree of tendency to seek extraordinary experience and based on the values concerning the preference of experiential learning two students were allocated with low sensation seeking tendency and who did not prefer experiential learning; two other students whose preferences in both areas were above average; one student with above-average sensation seeking tendency and below-average value in the case of experiential learning preference; the last student had inverted values: their SST was below-average and they had above-average preference of experiential learning. In total there were four female and two male students.

\subsection{Instrument and Procedures}

Two methods were used for data collection - questionnaire research and in-depth semi-structured interview. The questionnaire was derived from Questionnaire of learning styles, interests and hobbies and consisted of two standardized questionnaires. The first part comprised of a Questionnaire of learning styles (Mareš \& Slavík, 2004) and the second part of a Test of interests and hobbies (Kuban, 2006). The Test of interests and hobbies was included in complete form and only a few selected variables were used from the Questionnaire of learning styles. The main reason for selecting only certain variables was for better time-efficiency and prevention of follow-up degradation of the quality of answers in the second half of the questionnaire.

The in-depth semi-structured interview was structured by combining the list of questions and themes necessary to be addressed during the interview. The questions were devised to reflect variables, focusing on the particular types in the questionnaire to investigate respondents' favourite ways of learning, approaches to learning 
and circumstances they preferred in the learning process; finally, their tendency to seek extraordinary situations was examined. Developed from Hendl $(1999,2005)$ open questions and the interview structure were compiled. The interviews were carried out over a duration of three months, taking on average 45 minutes each.

\section{Questionnaire of learning styles, interests and hobbies}

Standardization of the Czech version of the Test of interests and hobbies was conducted in 2003 by Kuban (2006) and the original version was devised in 1978 by Zuckerman (1978) under the Sensation Seeking Scale form V (SSS-V). The SSS-V consists of forty items divided into four subscales with ten items in each subscale. The first subscale is Thrill and Adventure Seeking (TSA), which is an area of sports and physical activity. The second subscale is Experience Seeking (ES), the area of sensory perception. The third subscale is Disinhibition (Dis), the level of respect for legal, moral and social standards, and the fourth is Boredom Susceptibility (BS), the area of resistance to repeated stimuli. Each of the forty items contains two options that negate their importance to each other and maintains the form of forced choice. The total score expresses the SST of the tested persons, and their level of adaptation to new things and new situations in life or lifestyle changes (Kuban, 2006).

In 1967, Dunn and Dunn (1978) created an instrument called the Learning style questionnaire (LSQ). Until 1975 this questionnaire was tested and then renamed as the Learning style inventory (LSI). The Czech version was created from three independent translations by Pýchová, Kantorová and Mareš in 1992 (Mareš \& Skalská, 1994). The questionnaire investigates what individual students prefer during their studies, under what conditions they focus best, what they prefer when learning new or difficult subject matter and/or when they learn new skills. The questionnaire divides the questions by twenty-one variables, while in the questionnaire only eight were used. To falsify or confirm our hypothesis and to find out answers to the research question only the variable experiential learning was considered and evaluated.

\subsection{Data Analysis}

The calculations executed in the quantitative part of the research were undertaken via the statistical programme STATISTICA, version 9.0. Initially, the basic statistic quantities were calculated before Pearson's correlation coefficient was applied to identify the interrelations among individual subtests.

The qualitative part of the research departed from this method of framework analysis. The first step was to classify and reduce the data to be followed by the interpretation itself, leading to the explanatory report concerning the monitored field. Literal transcription and thematic analysis were carried out to compose a categorical system. The proposed categories present certain generalizations which stem from particular 
objective relations (Hendl, 2005). The transcribed texts with notes, codes and charts were used as representative means. The primary viewpoint concerning the data analysis was students' sensation seeking tendency, the way the students spend their free time, and their preferred learning styles.

\section{Research Results}

\subsection{Quantitative results}

Pearson's correlation coefficient for sensation seeking tendency and preference of experiential learning is $0.3092(p<.05000)$. Therefore, on the level of significance of $a=0.05$ it is possible to confirm the hypothesis $\mathrm{H}_{1}$ : there is a statistically significant correlation between the degree of sensation seeking tendency and the preference of experiential learning among students.

The hypothetical presupposition that the students with a higher tendency to seek extraordinary experience also appreciate the experience during their learning process, therefore they tend to prefer the so-called experiential learning more than students with a lower sensation seeking tendency.

\subsection{Qualitative results}

Two categories were created based on the preselected thematic fields and the obtained data. Each category was divided in several subcategories.

\subsubsection{Students' Experience during Learning}

Students remember things better which are imagined and visualised in movement.

A female student with a high level of SST in the experiential learning subscale score responded to the question concerning her experience during learning: “... I was learning about the limbs of insects. They are treading, scratching and other five similar categories - so I performed them for visualisation... I did this once and I have remembered them all for two weeks." Another female student with an above-average result in SST, on responding to the question concerning the understanding of experiential learning questions, provided an analogous answer: "... in Maths the logarithms are rising or falling exponentials, like when a plane is taking off, it is better, and while landing it is smaller, hence from 0 to 1. I need these kinda learning aids." In both cases the female students manifest correct understanding of the question, as well as showing the contribution of 
employing more senses into the learning process; thus, they are provided with space for illustrative examples, imagination, fantasy, feelings and experience.

\section{A male student rejecting the need for sensations during learning}

This interviewed student has a low level of both SST and of experiential learning, defined his need for experiential learning as follows: "Some feelings, dunno, like when the teacher is talking monotonously all the time, so nobody gives a damn, you know. Well, perhaps I don't need to experience anything... Speaking of a particular lesson, the teacher should not speak monotonously, this makes you sleepy. Otherwise no feelings, no." This student seems to demonstrate the wrong orientation to understand the question. He was not sure what the question entails; it is not connected with any particular imagination; he was clearly unaccustomed to expressing his feelings, even connecting his feelings concerning sensations with learning. Therefore, he probably chose a very low assessment of this question. It would be beneficial to know his answer if he had had any experience with experiential learning.

\section{A student uninterested and distorted in the lesson with "no" sensation during learning}

The interviewed student has both a low level of SST and experiential learning - 9 points and provided the following overview of his experience of teaching: "it may help from time to time. Sometimes I finally got into it... I have always been indifferent to Physics, so I will never remember it, like say, History, which interests me..." The question is understood here as a connection of "what interests me is appealing for me and thus easier to remember," which essentially is partly but not completely a correct interpretation. What is missing is a particular reasoning concerning how to start experiencing the learning process, how to induce sensations and consequently utilise them. The student lacks his own resources for how to induce the sensations; however, he is aware of the fact that when he is indifferent to a subject, having no sensation in the process, the learning effect lacks any quality.

\subsubsection{Student and Experiential Learning at School}

The conclusion of the interview contained a very brief and concise explanation of what experiential learning might entail ("... playing of various games, role-playing scenarios, drafting and realizing of student projects, outdoor stays and group works are utilized, students are immersed in activities whose execution or assessment induces sensations and emotions, their progress and results are being discussed..."). Consequently, the students were asked whether they do or had ever done anything similar. All those interviewed recalled at least one activity which resembled such planned activities. 
This was followed by questions regarding what the interviewees thought about such activities and how they perceived and experienced those.

\section{Students praising discussion as a means to remember facts from the lesson}

Students with high SST testify: "I think that was good. We perhaps better understood and remember more. Or at least I remember... well... how to... whether to pay the tuition fee or not. We were simply asked to compose groups according to those who are in favour and who are against, and then discuss things and stuff. It is the thing I remember something what my classmates are saying, that their opinions are. It is also better - the discussions like this... It is nice you know when we can say our bit."

\section{A student highlighting the elements of experiential learning as "good" for team spirit} One of the students achieving low SST comments on a music/visual arts course which he saw as a valuable contribution, mainly for the class team spirit. Although he generally stated low preferences for experiential learning, the course was evaluated as good and entertaining. The highest scoring student gave praise for a new experience which otherwise would not have been gained. Another student with low SST but a high level of experiential learning preference remembered a certain creative physical theatre/ dance project, which she described with excitement and the willingness to repeat and discuss. Such cases show particular evidence that students with a low SST may understand experiential learning activities or projects as entertaining and beneficial.

\section{Student praising an outdoor stay but otherwise rejecting experiential learning}

The only student who assessed their memories concerning an experientially conceived course negatively was a student with low SST, as well as a low preference for experiential learning. The referenced music/visual arts course was praised only because it enabled him to stay out of doors; other added benefits were not mentioned. The student could not recall any particular activity, which proves that the course had not appealed to him.

The discussed testimonies validate the view that experiential learning, or simply games, experiences, activities or otherwise alternatively conceived lessons are perceived positively. While discussing their need to experience the learning process, three out of six students reported very low values, however, in the actual interview five of them positively responded to such activities. 


\section{Discussion}

The individual degree of the SST is a personal characteristic, which, as Culková (2013) claims, in the case of secondary grammar school students can correlate with both preferred learning styles and gender. The present study substantiates that students with above-average sensation seeking tendency demand clearness and active learning. They prefer to experience the learning process and correctly relate to the questions from Questionnaire regarding learning styles, interests and hobbies with the variable of experiential learning. Students with below-average SST do not consider their own experience during the learning process. They do not have correct orientation in the questions from the experiential learning subscale; despite claiming in the questionnaire that they do not need to experience the learning process, based on in-depth interviews two out of three questioned would welcome experience-based learning. To a certain degree there was conflict between the values stated in the questionnaire and the spoken responses in the interview. One of the possible reasons could have been the fact that neither experience-based pedagogy nor any other experience-based learning methods were implemented in the common learning activities amongst the monitored group. Only those students who intuitively attempt to experience their educational process state as much in the questionnaire research. The students without contact with experiential learning or any inner need to experience this struggled in the questionnaire; the disagreement in their spoken and written response could perhaps be interpreted as a misunderstanding of the questionnaire.

The present study observes that the students with above-average SST would welcome frequent use of experience-based learning at school. Klevetová and Dlabalová (2008) advocate that we remember most, up to $80 \%$, from what we do and experience directly. Therefore, by initiating an emotion during the learning process, the process of remembering becomes more efficient. We take a completely different attitude towards the subject that is of our present interest or which resonates with our personal aims, rather than to something that is neither enjoyable nor interesting for us. Furthermore, the ability to saturate the need for sensations in class among certain students can decrease unwanted behaviours. If the need for sensations is not fully satisfied, frequent occurrences such as "disobedience," "interrupting" or other phenomena complicating the learning process can appear. Positive intellectual results depend highly on choosing right teaching methods (Wentzel, 1993).

The execution of similar research would be beneficial among the students acquainted with experience-based pedagogy and could consequently focus on the monitoring of learning outputs in relation with the preferred learning style. 


\section{Conclusions}

The present study posed two research questions and one alternative hypothesis. On the level of significance of $\alpha=0.05$ the alternative hypothesis $H_{1}$ has been verified: there is a statistically significant correlation between the sensation seeking tendency and the preference of experiential learning. The verification of the prescribed hypothesis has partially answered the first research question: is it possible to find a statistically significant correlation between the degree of sensation seeking tendency and preferences of experiential learning?

The second research question was equally answered. How do students with high and low sensation seeking tendencies consider their need to experience the learning process? Students with a high degree of sensation seeking tendency need to experience the learning process both intuitively and deliberately; they seek new means to do it for themselves and welcome experience-based activities in lessons or in any other school activities. Two out of three students with a low degree of sensation seeking tendency lack the inner need to experience the learning process, but welcome activities containing elements of experience-based pedagogy if available.

The study has brought a pragmatic analysis of students' experience in the educational process to an institution which normally does not apply methods of experiential pedagogy. Therefore, the study shows the need to experience the educational process among students who otherwise feel such a need merely intuitively. This urge is frequently connected with the so-called sensation seeking tendency. By realizing these individual needs, respecting these while considering students' learning styles, and attempting to adjust the learning process to individual factors, we can speak of an improved educational process. The present study thus contributes educational process discourse with another possible perspective.

\section{References}

Ang, R. P., \& Woo, A. (2003). Influence of sensation seeking on boys' psychological adjustment. North American Journal of Psychology, 5(1), 121-136.

Blum, R. W., Beuhring, T., \& Rinehart, P. M. (2000). Protecting teens: Beyond race, income, and family structure. Minneapolis, MN: University of Minnesota Printing Services.

Carter, S. P., \& Stewin, L. L. (1999). School violence in the Canadian context: An overview and model for intervention. International Journal for the Advancement of Counseling, 21(4), 267-277.

Culková, D. (2013). Vyhledávání mimořádných prožitků a preference učebního stylu studenta (Sensation Seeking and Learning Style Preferences). Pedagogická orientace, 23(3), 364-385.

Dunn, R., Dunn, K., \& Price, G. E. (1989). Learning style inventory. Lawrence: Price System, Inc.

Hendl, J. (1999). Úvod do kvalitativního výzkumu (Introduction to Qualitative Research) Praha: Karolinum.

Hendl, J. (2005). Kvalitativní výzkum: Základní metody a aplikace (Qualitative Research: Basic Methods and Applications). Praha: Portál. 
Klevetová, D. \& Dlabalová, I. (2008). Motivační prvky při práci se seniory (Motivational Elements When Working with Seniors). Praha: Grada.

Krásová, P., \& Rost, M. (2008): Tendence vyhledávat mimořádné prožitky u vysokoškoláků ve vztahu k osobnostním charakteristikám (Sensation Seeking Tendency of University Students in Relation to Personality Trait). Studia Kinanthropologica, 2(9), 238-245.

Kuban, J. (2001). Komparace Sensation Seeking Tendency u hráčů sportovních her (Sensation Seeking Tendency Comparison among Sport Games Players). In. Čepička, L. (Ed.), Hry v programech tělovýchovných procesů (pp. 41-46). Plzeň: Západočeská univerzita

Kuban, J. (2006). Tendence k vyhledávání prožitku a její diagnostika (Sensation Seeking Tendency and its Diagnostics). Hradec Králové: Gaudeamus.

Mareš, J., \& Skalská, H. (1994). LSI - dotaznik stylů učeni pro žáky základních a středních škol (LSI Learning Style Inventory for Primary and Secondary Schools Pupils). Psychológia a patopsychológia dietááa, 29(3), 248-264.

Mareš, J., \& Slavík, V. (2004). Dotazník stylu učení (Learning Style Inventory). Praha: IPPP ČR.

Rybenský, D. (2008). Konstrukce standardů pro test prožitkovosti - Sensation Seeking Tendency (česká verze) (Standards Construction of Sensation Seeking Scale (Czech Version)). Diplomová práce. Hradec Králové: Univerzita Hradec Králové, Pedagogická fakulta.

Wentzel, K. R. (1993). Social and academic goals at school: Motivation and achievement in early adolescence. Journal of Early Adolescence, 13(1), 4-20.

Zuckerman, M. (1978). Sensation seeking. In London, H. \& Exner, J. (Eds.), Dimensions of personality (pp. 487-555). New York: Wiley.

Zuckerman, M. (1994). Behavioral expressions and biosocial bases of sensation seeking. Cambridge: Cambridge University Press.

Zuckerman, M. (July 2001). Personality and risk taking. Tenth Biennial Meeting of the International Society for the Study of Individual Differences. Edinburgh: The University of Edinburgh.

\section{Contact:}

Mgr. Dita Culková, Ph.D.

http://culkova.webnode.cz/

Department of Physical Education and Sports

Mgr. Jan Suk, Ph.D.

Department of English Language and Literature

Faculty of Education, University of Hradec Králové

Rokitanského 62, 50003 Hradec Králové

Czech Republic.

E-mails: dita.culkova@uhk.cz,jan.suk@uhk.cz

Mgr. Dita Culkova, Ph.D. is an assistant professor at the Department of Physical Education and Sport, Faculty of Education, University of Hradec Králové, where she teaches Physical Education to future nursery and primary school teachers. She obtained her doctoral degree from Kinanthropology and undertook psychotherapeutic training in Integrative Psychotherapy. She specializes in sensation-seeking pedagogy, physical education didactics, Psychomotorics, sport psychology, sport and movement activities, and finally, outdoor sports. Furthermore, she teaches Physical Education at elementary school focused on the Jena Plan school programme. Her specialisation is free time programmes for parents and children. 
Mgr. Jan Suk, Ph.D. teaches at the Department of English Language and Literature, Faculty of Education, University of Hradec Králové. Jan Suk took his PhD at Faculty of Arts, Charles University, Prague. His dissertation thesis examined the rich practice of contemporary British experimental theatre Forced Entertainment via Deleuzoguattarian prism. His monograph called The Poetics of Immanence: Performance Theatre of Forced Entertainment is being published at De Gruyter Publishing House in 2019. He has lectured internationally, e.g. at Stanford University, King's College in London or SAIC Chicago. His most recent research interests include performance and/as pedagogy or proximity and/of performance theatre.

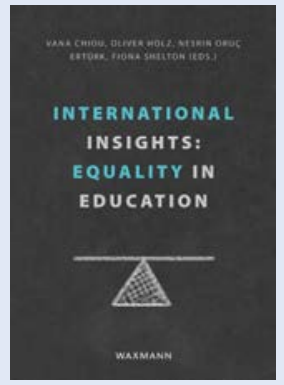

Chiou, Vana; Holz, Oliver; Oruç Ertürk, Nesrin; Shelton, Fiona (Eds.). International Insights: Equality in Education. Münster: Waxmann, 2019. ISBN 978-3-8309-4022-7.

Educational institutions should offer a safe and secure environment for young people. Part of that should be educational equity, which is a measure of achievement, fairness, and opportunity in education. This publication analyses and discusses educational equality from different angles. All contributions reflect on the current situation of 11 European countries. All of them are part of the Bologna process and are dealing with the challenges of the development of a European Higher Education Area. This ongoing process is reflected in the present publication, with a specific focus on equality in education.

The authors cover aspects like inclusion and inequality, internationalizing education, and accessing education, but they also deal with learning foreign languages, education for the future, assessment, feedback and student success, lifelong learning, teacher training as well as different aspects of the $L G B(T+)$ community and gender and education. 